Atmos. Chem. Phys. Discuss., 4, 5381-5405, 2004

www.atmos-chem-phys.org/acpd/4/5381/

SRef-ID: 1680-7375/acpd/2004-4-5381

(C) European Geosciences Union 2004
Atmospheric

Chemistry and Physics Discussions

\title{
Atmospheric pseudohalogen chemistry
}

D. J. Lary ${ }^{1,2,3}$

${ }^{1}$ Global Modelling and Assimilation Office, NASA Goddard Space Flight Center, Greenbelt, MD, USA

${ }^{2}$ GEST at the University of Maryland Baltimore County, Baltimore, MD, USA

${ }^{3}$ Unilever Cambridge Centre, Dep. of Chemistry, University of Cambridge, Cambridge, UK

Received: 29 July 2004 - Accepted: 1 September 2004 - Published: 16 September 2004

Correspondence to: D. J. Lary (david.lary@umbc.edu)

ACPD

4, 5381-5405, 2004

Atmospheric

pseudohalogen

chemistry

D. J. Lary

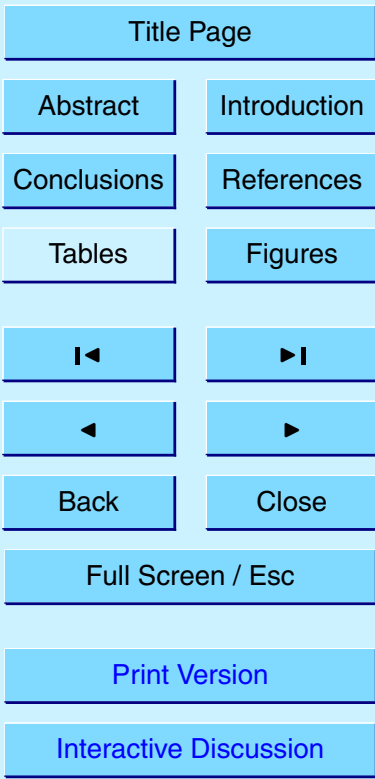

(C) EGU 2004 


\section{Abstract}

There are at least three reasons why hydrogen cyanide is likely to be significant for atmospheric chemistry. The first is well known, $\mathrm{HCN}$ is a product and marker of biomass burning. However, if a detailed ion chemistry of lightning is considered then it is almost

5 certain than in addition to lightning producing $\mathrm{NO}_{\mathrm{x}}$, it also produces $\mathrm{HO}_{\mathrm{x}}$ and $\mathrm{HCN}$. Unlike $\mathrm{NO}_{\mathrm{x}}$ and $\mathrm{HO}_{\mathrm{x}}, \mathrm{HCN}$ is long-lived and could therefore be a useful marker of lightning activity. Observational evidence is considered to support this view. Thirdly, the chemical decomposition of HCN leads to the production of small amounts of $\mathrm{CN}$ and NCO. $\mathrm{NCO}$ can be photolyzed in the visible portion of the spectrum yielding $\mathrm{N}$ atoms. The sphere via $\mathrm{N}+\mathrm{N} \rightarrow \mathrm{N}_{2}$. Normally the only modelled source of $\mathrm{N}$ atoms is $\mathrm{NO}$ photolysis which happens largely in the UV Schumann-Runge bands. However, NCO photolysis occurs in the visible and so could be involved in titration of atmospheric nitrogen in the lower stratosphere and troposphere. HCN emission inventories are worthy of atten-

\section{Introduction}

Since the discovery of the Antarctic ozone hole by Farman et al. (1985) the importance of halogen radicals in determining the concentrations of atmospheric ozone has been clearly demonstrated. However, it was only in the mid 1970s that the halogen radicals were first recognized as a potential threat to ozone. In like manner, there may be other radicals which play a role in ozone photochemistry. There are many natural and anthropogenic sources of compounds containing $\mathrm{CN}$ which can be released into the
ACPD

4, 5381-5405, 2004

Atmospheric

pseudohalogen

chemistry

D. J. Lary

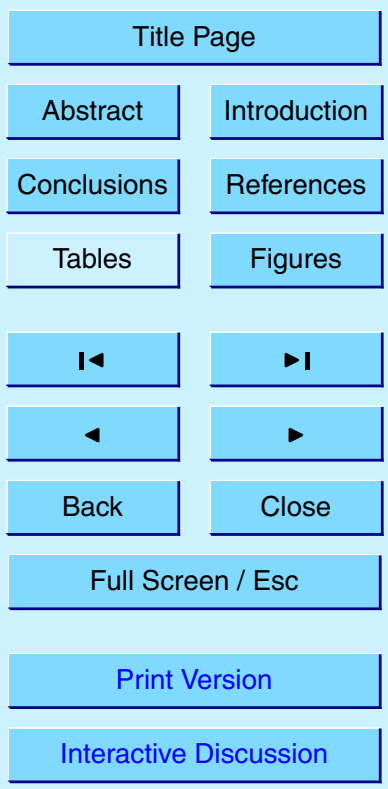

(C) EGU 2004 
atmosphere. Many $\mathrm{CN}$ reactions are already considered when studying combustion chemistry and interstellar clouds. This paper considers their importance in our own atmosphere.

\subsection{Properties}

$5 \mathrm{HCN}$ (also called formonitrile) is a highly volatile, colorless, and extremely poisonous liquid (boiling point $26^{\circ} \mathrm{C}$, freezing point $-14^{\circ} \mathrm{C}$ ). A solution of hydrogen cyanide in water is called hydrocyanic acid, or prussic acid. It was discovered in 1782 by the Swedish chemist, Carl Wilhelm Scheele, who prepared it from the pigment Prussian blue (Britannica, 2003).

\subsection{Observations}

It is surprising that $\mathrm{HCN}$ is so often overlooked as it has been observed on numerous occasions over the last two decades (Yokelson et al., 2003; Singh et al., 2003; Zhao et al., 2002; Rinsland et al., 2001, 2000; Zhao et al., 2000; Rinsland et al., 1999; Bradshaw et al., 1998; Rinsland et al., 1998a,b; Schneider et al., 1997; Mahieu et al., 1997;

15 Rinsland et al., 1996; Notholt et al., 1995; Mahieu et al., 1995; Toon et al., 1992b,a; Kopp, 1990; Jaramillo et al., 1989; Zander, 1988; Carli and Park, 1988; Jaramillo et al., 1988; Abbas et al., 1987; Smith and Rinsland, 1985; Coffey et al., 1981). Recently it has sometimes been considered as an "interference" for $\mathrm{NO}_{\mathrm{y}}$ observations, for example, Bradshaw et al. (1998); Thompson et al. (1997); Kliner et al. (1997). However, regarding it as an "interference" overlooks its potential importance in atmospheric chemistry, particularly as Cicerone and Zellner (1983) deduced that HCN has a very long residence time against rainout.

Figure 1 shows all the HCN observations made by the Atmospheric Trace Molecule Spectroscopy Experiment (ATMOS) on the missions ATLAS-1, ATLAS-2, and ATLAS-3 (Rinsland et al., 1998a,b, 1996) together with a typical mid-latitude $\mathrm{NO}_{\mathrm{y}}$ profile. In the upper troposphere and lower stratosphere the HCN abundance is comparable to the

\section{Atmospheric pseudohalogen chemistry}

D. J. Lary

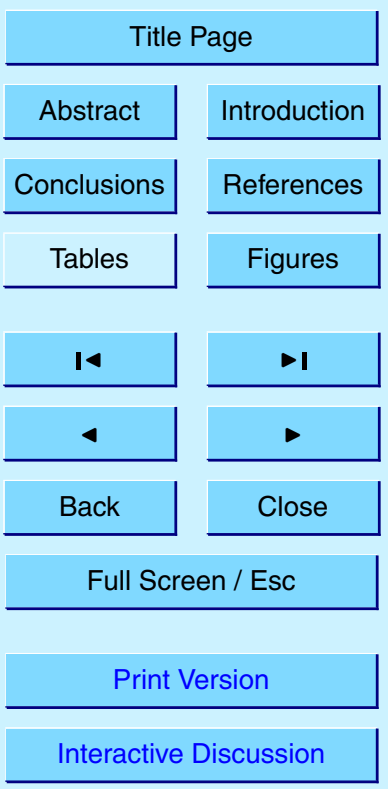

(C) EGU 2004 
$\mathrm{NO}_{y}$ present and should not be neglected. It is tantalizing that some of the tropical vertical profiles seem to have a large peak in HCN close to the tropopause which may be produced by lightning in regions of strong convective activity.

\subsection{Likely sources}

5 HCN is produced by biomass burning (Lobert et al., 1990; Hurst et al., 1994b; Yokelson et al., 1997b; Holzinger et al., 1999; Rinsland et al., 1999, 2000; Barber et al., 2003; Li et al., 2003; Singh et al., 2003; Yokelson et al., 2003) since nitrogen in plant material is mostly present as amino acids and upon combustion this nitrogen is emitted as a variety of compounds including $\mathrm{NH}_{3}, \mathrm{NO}, \mathrm{NO}_{2}, \mathrm{~N}_{2} \mathrm{O}$, organic nitriles and nitrates 10 (Holzinger et al., 1999; Yokelson et al., 1997a; Lee and Atkins, 1994; Hurst et al., 1994b,a; Kuhlbusch et al., 1991). There are many naturally occurring substances yielding cyanide in their seeds, such as the pit of the wild cherry. It usually occurs in combination with plant sugars. The tuberous edible plant of the spurge family called cassava (also known as manioc, mandioc, or yuca) were used by primitive peoples to produce $\mathrm{HCN}$ for poison darts and arrows. HCN is produced by other plants, bacteria and fungi.

In addition, aliphatic-amines are produced from animal husbandry and may be a source of HCN (Schade and Crutzen, 1995). Schade and Crutzen (1995) measured the emissions of volatile aliphatic amines and ammonia produced by the manure of 20 beef cattle, dairy cows, swine, laying hens and horses in livestock buildings. The amine emissions consisted almost exclusively of the three methylamines and correlated with those of ammonia. Schade and Crutzen (1995) showed possible reaction pathways for atmospheric methylamines. These included the speculative but possible production of $\mathrm{HCN}$.

25 There are many anthropogenic sources of compounds containing $\mathrm{CN}$ which can be released into the atmosphere. Cyanides are used in a variety of chemical processes including fumigation, case hardening of iron and steel, electroplating and in the concentration of ores. Hydrogen cyanide is a highly volatile and extremely poisonous gas
ACPD

4, 5381-5405, 2004

Atmospheric

pseudohalogen

chemistry

D. J. Lary

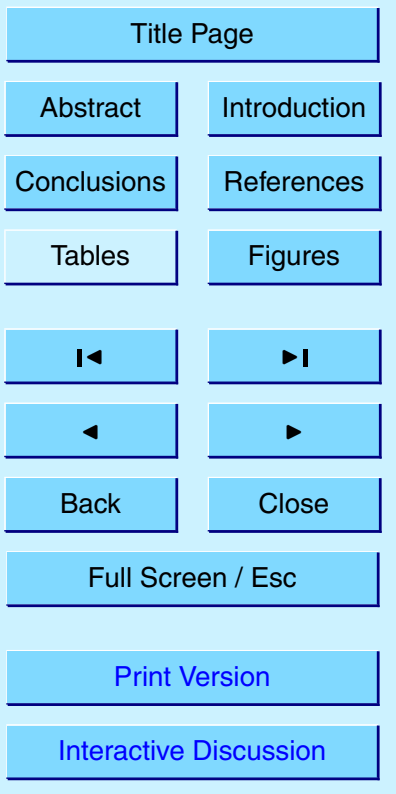

(c) EGU 2004 
that is used in fumigation, ore concentration, and various other industrial processes. Cyanogen, or oxalonitrile, $(\mathrm{CN})_{2}$, is also used as a chemical intermediate and a fumigant. Hydrogen cyanide is used to prepare polyacrylonitrile fibres (known by the generic name of acrylic) synthetic rubber, plastics, and in gas masers to produce a 5 wavelength of $3.34 \mathrm{~mm}$ (Britannica, 2003). Acrylic fibres are spun from polymers consisting of at least $85 \%$ by weight of acrylonitrile units produced from ethylene oxide and hydrocyanic acid.

Hydrogen cyanide is a combustion product which is a human hazard during domestic and industrial fires. Some catalytic converters in bad repair can produce large amounts 10 of Hydrogen cyanide. Hydrogen cyanide is produced in large quantities for laboratory and commercial use by three principal methods: Treatment of sodium cyanide with sulphuric acid, catalytic oxidation of a methane-ammonia mixture, and decomposition of formamide $\left(\mathrm{HCONH}_{2}\right)$.

We suggest that it is timely to compile $\mathrm{HCN}$ emission inventories.

15 It is interesting to note that the atmospheric measurements of $\mathrm{HCN}$ reported by Zander (1988) gave a mixing ratio for HCN in the Southern Hemisphere which was approximately $5 \%$ higher than that for the Northern Hemisphere. This may be due to biomass burning. It seems that in addition to HCN being a marker of biomass burning it is also a marker for lightning.

20 1.4. $\mathrm{HCN}, \mathrm{HO}_{\mathrm{x}}$ and lightning

Emissions from $\mathrm{CN}$ radicals are occasionally observed from lightning disturbed air (Cicerone and Zellner, 1983). In the atmosphere of Jupiter HCN is present with a concentration of about 2 ppbv and is thought to be produced by lightning in the convective regions of Jupiter's atmosphere (Britannica, 2003; Borucki et al., 1988, 1991). On Titan $25 \mathrm{HCN}$ is also thought to be produced by lightning (Borucki et al., 1988). It may well be that lightning is a significant source of $\mathrm{HCN}$, particularly due to its resistance to uptake by aqueous media.

Lightning produces large scale ionisation in the atmosphere with temperatures of
ACPD

$4,5381-5405,2004$

Atmospheric

pseudohalogen chemistry

D. J. Lary

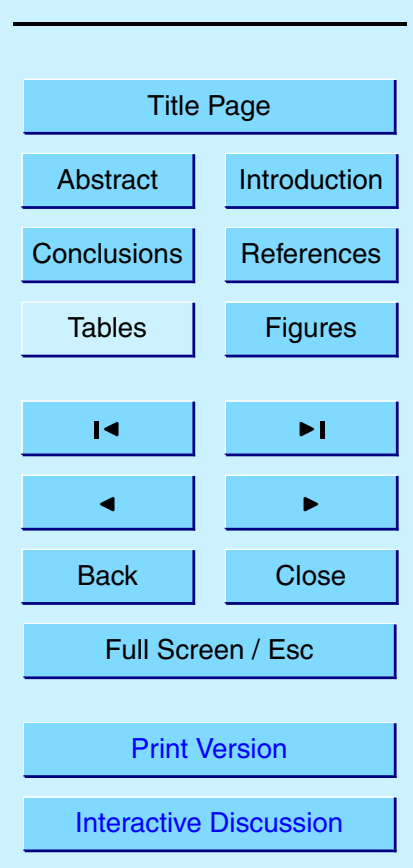

(c) EGU 2004 
around $30000 \mathrm{~K}$ produced within a few microseconds. Both the ionisation and high temperatures are significant for atmospheric chemistry, and the full implications are usually completely overlooked, with attention paid almost exclusively to $\mathrm{NO}_{\mathrm{x}}$. Ionisation produced by cosmic rays and precipitating particles is well known to produce $\mathrm{NO}_{\mathrm{x}}$ and $5 \mathrm{HO}_{\mathrm{x}}$ (Brasseur and Solomon, 1987). The ionisation associated with lightning is between six and fifteen orders of magnitude greater than that associated with cosmic rays (Boldi, 1992). It is therefore likely that elevated $\mathrm{HO}_{\mathrm{x}}$ should be associated with lightning (Hill, 1992). This has been both calculated (Boldi, 1992) and hinted at by observations of elevated $\mathrm{HO}_{\mathrm{x}}$ in the vicinity of convective outflow (Jaegle et al., 1999). Calculations 10 suggest that there is a $5-6 \%$ increase in global lightning for every $1^{\circ} \mathrm{C}$ of warming (Price and Rind, 1994), so if there is a lightning source of $\mathrm{HO}_{\mathrm{x}}$ global warming could lead to a significant change in the oxidizing capacity of the atmosphere due to lightning produced $\mathrm{HO}_{\mathrm{x}}$ alone.

Equilibrium thermodynamic calculations (Boldi, 1992) show that for the conditions 15 associated with a lightning strike in the terrestrial atmosphere we would expect between 0.7 to $1 \mathrm{ppbv}$ of $\mathrm{HCN}$. If $\mathrm{HCN}$ is produced by lightning, then in the surrounding air we would simultaneously expect elevated concentrations of both $\mathrm{NO}_{\mathrm{x}}$ and $\mathrm{NO}_{\mathrm{y}}$. This is exactly what ATMOS observed (ATMOS). For example, around a thousand observations of HCN were made during November 1994 as part of ATLAS3 (ATMOS). Among these observations there were six anomalously high $\mathrm{HCN}$ observations of greater than 0.7 ppbv, for which elevated concentrations of both $\mathrm{NO}_{x}$ and $\mathrm{NO}_{y}$ were also observed. If one plots a scatter diagram of the $\mathrm{HCN}$ against $\mathrm{NO}_{x}$ concentrations (Fig. 2), we find that there is a strong correlation between $\mathrm{HCN}$ and $\mathrm{NO}_{x}$ for high $\mathrm{HCN}$ concentrations. This corresponds to the air parcels that have probably recently encountered lightning. 25 There is not a strong correlation for the lower $\mathrm{HCN}$ and $\mathrm{NO}_{\mathrm{x}}$ concentrations as $\mathrm{NO}_{\mathrm{x}}$ and $\mathrm{HCN}$ are not in chemical equilibrium.

There are several satellites which observe global lightning, but these had not been launched at the time of the last ATMOS mission. However, for the six locations with $\mathrm{HCN}$ concentrations greater than $0.7 \mathrm{ppbv}$ visible satellite images show cloud cover
ACPD

4, 5381-5405, 2004

Atmospheric

pseudohalogen

chemistry

D. J. Lary

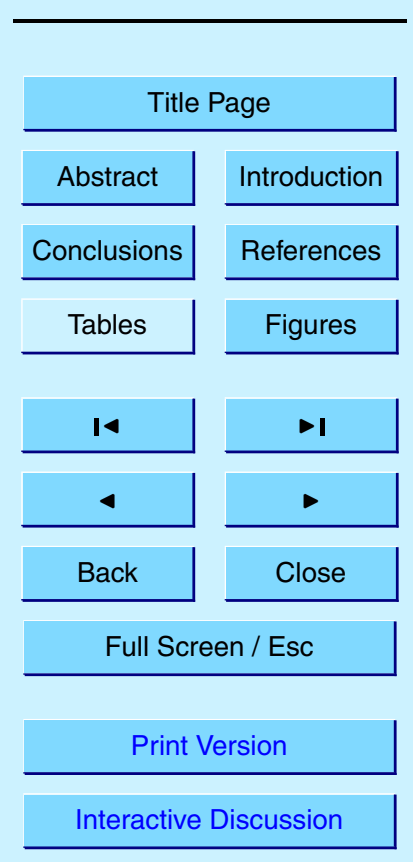

(c) EGU 2004 
as do the NCEP analyses (NCEP). Each of the six locations were in a costal region or over land which is where most lightning activity occurs. The vertical structure of the $\mathrm{HCN}$ profile may provide a good test for the hypothesis that $\mathrm{HCN}$ is produced by lightning. During thunderstorms we expect a " $\mathrm{C}$ " shaped $\mathrm{NO}_{\mathrm{x}}$ profile (Pickering et al., 5 1998), and so should also expect a "C" shaped HCN profile with enhanced HCN in the region between 5 and $14 \mathrm{~km}$.

\subsection{Previous modelling work}

The only previous modelling studies of atmospheric HCN appear to be those of $\mathrm{Ci}$ cerone and Zellner (1983); Brasseur et al. (1985); Li et al. (2003); Singh et al. (2003) who considered the earth's current atmosphere and the studies of Zahnle (1986a,b) who presented a study of the likely HCN chemistry in the earth's early atmosphere. Cicerone and Zellner (1983) identified the major atmospheric losses of HCN. Li et al. (2003) and Singh et al. (2003) showed that the main HCN loss is due to oceanic uptake.

This study expands the previous work by considering many $\mathrm{N}, \mathrm{CN}$ and NCO re-

\section{Reasons to consider HCN}

Before systematically examining atmospheric $\mathrm{CN}_{\mathrm{x}}$ chemistry let us examine at least three reasons why we should consider atmospheric HCN chemistry.
ACPD

$4,5381-5405,2004$

Atmospheric

pseudohalogen

chemistry

D. J. Lary

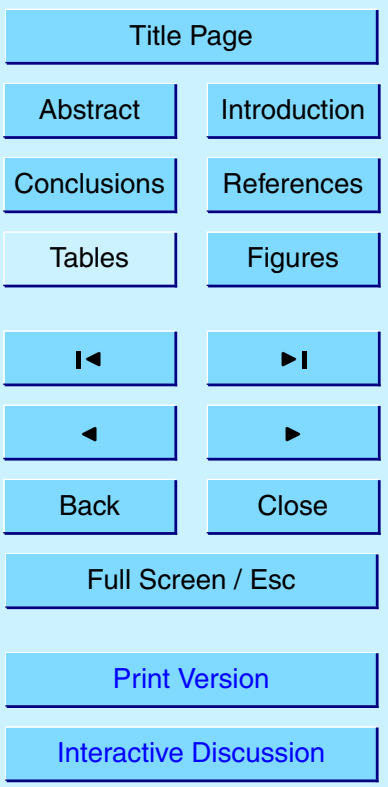

(C) EGU 2004 


\subsection{Abundance}

Figure 1 shows that in the upper troposphere and lower stratosphere the HCN abundance is comparable to the $\mathrm{NO}_{\mathrm{y}}$ present.

\subsection{Tracer}

$5 \mathrm{HCN}$ is a long lived, low solubility (Cicerone and Zellner, 1983) gas. If as it seems $\mathrm{HCN}$ is produced by lightning (Britannica, 2003; Cicerone and Zellner, 1983; Borucki et al., 1988, 1991) then as it is not rained out it may well prove to be an effective tracer of lightning activity. Such a marker could be extremely valuable to complement observations (Huntrieser et al., 1998; Kawakami et al., 1997; Hauf et al., 1995).

\section{3. $\mathrm{N}$ atom source}

The main stratospheric sink of $\mathrm{NO}_{\mathrm{y}}$ is the reaction of $\mathrm{N}$ with $\mathrm{NO}$

$\mathrm{N}+\mathrm{NO} \longrightarrow \mathrm{N}_{2}+\mathrm{O}\left({ }^{3} \mathrm{P}\right)$

with the main source of $\mathrm{N}$ atoms generally accepted to be the photolysis of NO

$\mathrm{NO}+\mathrm{h} v \rightarrow \mathrm{N}+\mathrm{O}\left({ }^{3} \mathrm{P}\right) \lambda \leq 189 \mathrm{~nm}$.

15 However, the photolysis of NCO is also a source of $\mathrm{N}$ atoms. The rate of $\mathrm{N}$ production due to NCO photolysis is calculated to be faster than that due to NO photolysis below about $10 \mathrm{~km}$.

$\mathrm{NCO}+\mathrm{h} v \longrightarrow \mathrm{N}+\mathrm{CO} \lambda \leq 342 \mathrm{~nm}$.

Consequently, when pseudohalogen chemistry is included in the model there is a significant increase (more than an order of magnitude) in the $\mathrm{N}$ atom concentration below $10 \mathrm{~km}$ (Fig. 4).
ACPD

$4,5381-5405,2004$

Atmospheric

pseudohalogen

chemistry

D. J. Lary

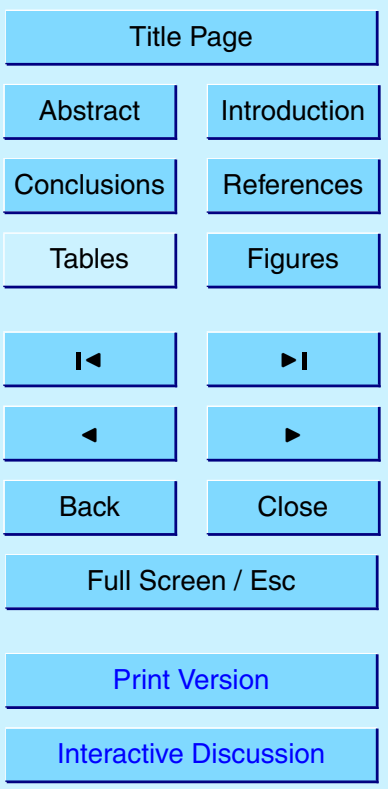

(C) EGU 2004 


\section{Atmospheric $\mathrm{CN}_{\mathrm{x}}$ chemistry}

Let us now consider the HCN chemistry depicted in Fig. 3 as simulated using the extensively validated AutoChem model (Lary et al., 1995; Fisher and Lary, 1995; Lary, 1996; Lary et al., 2003). The model is explicit and uses the adaptive-timestep, error

5 monitoring, Stoer and Bulirsch (1980) time integration scheme designed by Press et al. (1992) for stiff systems of equations. Photolysis rates are calculated using full spherical geometry and multiple scattering (Anderson, 1983; Lary and Pyle, 1991a,b; Meier et al., 1982; Nicolet et al., 1982) corrected after Becker et al. (2000). The photolysis rate used for each time step is obtained by ten point Gaussian-Legendre integration 10 (Press et al., 1992). In this study the model described a total of 49 species including CN, NCO and HCN. The model kinetic data is based on DeMore et al. (2000) with the cyanide reactions coming from a variety of sources.

The eventual fate of most $\mathrm{HCN}$ released into the atmosphere is NO. Since HCN has a long lifetime against rainout (Cicerone and Zellner, 1983), whereas $\mathrm{NO}_{\mathrm{x}}$ does not, $15 \mathrm{HCN}$ can be transported from the regions where it is emitted and slowly release $\mathrm{NO}_{\mathrm{x}}$ away from the source regions. The net effect of $\mathrm{HCN}$ oxidation is summarized by the following reaction sequence shown in the following:

$$
\begin{aligned}
& \mathrm{HCN}+\mathrm{OH} \longrightarrow \mathrm{H}_{2} \mathrm{O}+\mathrm{CN} \\
& \mathrm{CN}+\mathrm{O}_{2} \longrightarrow \mathrm{NCO}+\mathrm{O}
\end{aligned}
$$

$20 \mathrm{NCO}+\mathrm{h} v \longrightarrow \mathrm{N}+\mathrm{CO}$

$\mathrm{N}+\mathrm{O}_{2} \longrightarrow \mathrm{NO}+\mathrm{O}$

$2 \mathrm{O}+2 \mathrm{O}_{2} \longrightarrow 2 \mathrm{O}_{3}$

$\mathrm{O}_{3}+\mathrm{hv} \longrightarrow \mathrm{O}\left({ }^{1} \mathrm{D}\right)+\mathrm{O}_{2}$

$\mathrm{O}\left({ }^{1} \mathrm{D}\right)+\mathrm{H}_{2} \mathrm{O} \longrightarrow 2 \mathrm{OH}$

25 Net: $\mathrm{HCN}+3 \mathrm{O}_{2}+2 \mathrm{hv} \longrightarrow \mathrm{CO}+\mathrm{O}_{3}+\mathrm{NO}+\mathrm{OH}$

Therefore including $\mathrm{HCN}$ chemistry provides a small additional source of $\mathrm{NO}_{\mathrm{x}}, \mathrm{O}_{3}$ and 5389
ACPD

$4,5381-5405,2004$

Atmospheric

pseudohalogen

chemistry

D. J. Lary

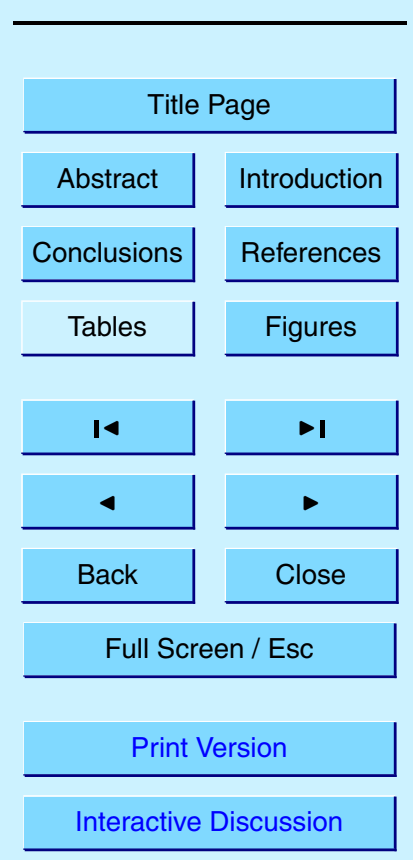

(c) EGU 2004 
$\mathrm{CO}$. If there is a heterogeneous conversion (oxidation) of $\mathrm{HCN}$ then it may be more important than described here, particularly in the upper troposphere.

\section{1. $\mathrm{HCN}$}

Figure 1 shows the observed HCN profiles from ATMOS. Cicerone and Zellner (1983) 5 and Brasseur et al. (1985) were able to reproduce the tropospheric portion of the profile but not the stratospheric portion. They suggested that the discrepancy may be due to an inappropriate $\mathrm{OH}$ concentration or $\mathrm{HCN}$ photolysis rate. The $\mathrm{HCN}$ photolysis rate calculated by assuming $\mathrm{HCN}$ has the same absorption cross-section as $\mathrm{HCl}$ will be too fast as Herzberg and Innes (1957) report a predissociation limit of $179 \mathrm{~nm}$ for HCN, which means that the HCN photolysis rate is very small. This is confirmed by the calculations of Huebner et al. (1992).

Another likely possibility for the discrepancy is in-situ atmospheric production of HCN. Such production can occur by several routes, most of which are very slow as they involve the $\mathrm{CN}$ radical which is quickly removed by reaction with $\mathrm{O}_{2}$. For this 15 reason, an effective production will probably not involve CN. Zahnle (1986a) included the production of $\mathrm{HCN}$ caused by the reaction of $\mathrm{N}$ with $\mathrm{CH}_{2}$ and $\mathrm{CH}_{3}$. Since $\mathrm{CH}_{2}$ is produced mainly by Lyman- $\alpha \mathrm{CH}_{4}$ photolysis, this source of $\mathrm{HCN}$ will be small in the troposphere and stratosphere (these source are included in the model). The reaction of $\mathrm{N}$ with $\mathrm{CH}_{4}$ is the most important source of $\mathrm{HCN}$ in the model, and has a noticeable effect on the calculated $\mathrm{HCN}$ concentration above $25 \mathrm{~km}$. It was not included by Cicerone and Zellner (1983); Brasseur et al. (1985); Zahnle (1986a,b). The rate constant was measured by Takahashi (1972) at $298 \mathrm{~K}$ with $\mathrm{N}_{2}$ as the bath gas as $2.5 \times 10^{-14}$ molecules ${ }^{-1} \mathrm{~cm}^{3} \mathrm{~s}^{-1}$.

$\mathrm{N}+\mathrm{CH}_{4} \longrightarrow \mathrm{HCN}+\mathrm{H}_{2}+\mathrm{H}$.

25 Ocean uptake is the dominant sink for HCN (Singh et al., 2003; Li et al., 2003). The main atmospheric loss of $\mathrm{HCN}$ is reaction with $\mathrm{OH}$.

$\mathrm{HCN}+\mathrm{OH} \longrightarrow \mathrm{H}_{2} \mathrm{O}+\mathrm{CN}$
ACPD

4, 5381-5405, 2004

Atmospheric

pseudohalogen

chemistry

D. J. Lary

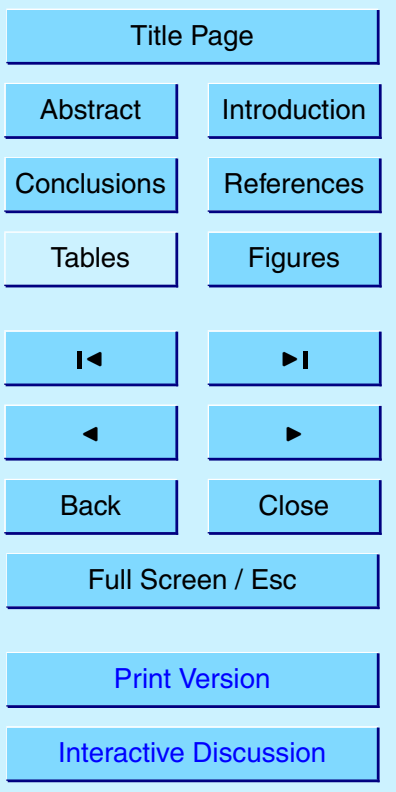

(C) EGU 2004 
If the $\mathrm{HCl}$ cross-section is used to calculate the $\mathrm{HCN}$ photolysis rate as was done by Cicerone and Zellner (1983) and Brasseur et al. (1985) then above $35 \mathrm{~km}$ photolysis is the most important loss of HCN. However, Herzberg and Innes (1957) report a predissociation limit of $55900 \mathrm{~cm}^{-1}, 179 \mathrm{~nm}$. This means that no photolysis would occur in 5 the important UV window and HCN photolysis is very slow.

$\mathrm{HCN}+\mathrm{h} v \longrightarrow \mathrm{H}+\mathrm{CN} \quad \lambda \leq 179 \mathrm{~nm}$.

There is also a minor loss due to reaction with $O\left({ }^{3} \mathrm{P}\right)$ and $\mathrm{O}\left({ }^{1} \mathrm{D}\right)$ (Fig. 4).

$\mathrm{HCN}+\mathrm{O}\left({ }^{3} \mathrm{P}\right) \longrightarrow \mathrm{H}+\mathrm{NCO}$

$\mathrm{HCN}+\mathrm{O}\left({ }^{1} \mathrm{D}\right) \longrightarrow \mathrm{OH}+\mathrm{CN}$

10 3.2. The cyanide radical, $\mathrm{CN}$

In the sunlit atmosphere $\mathrm{CN}$ is in photochemical equilibrium. $\mathrm{CN}$ has a very short lifetime because of the very fast reaction of $\mathrm{CN}$ with $\mathrm{O}_{2}$. The lifetime varies between about $10 \mathrm{~ns}$ and $60 \mu \mathrm{s}$. The calculated CN profile is shown in Fig. 4.

The most important production channel for $\mathrm{CN}$ in the model $\mathrm{km}$ is

$15 \mathrm{HCN}+\mathrm{OH} \longrightarrow \mathrm{H}_{2} \mathrm{O}+\mathrm{CN}$.

The reaction is slightly endothermic at $298 \mathrm{~K}$, however, the reverse reaction is not a significant source of $\mathrm{HCN}$. In the upper atmosphere the reaction of $\mathrm{HCN}$ with $\mathrm{O}\left({ }^{1} \mathrm{D}\right)$ and $\mathrm{HCN}$ photolysis each contribute a few percent to the overall production of $\mathrm{CN}$.

$\mathrm{HCN}+\mathrm{O}\left({ }^{1} \mathrm{D}\right) \longrightarrow \mathrm{OH}+\mathrm{CN}$.

20 The main loss of $\mathrm{CN}$ at all altitudes in the model is the rapid reaction of $\mathrm{CN}$ with $\mathrm{O}_{2}$ which has two channels

ACPD

4, 5381-5405, 2004

\section{Atmospheric \\ pseudohalogen \\ chemistry}

D. J. Lary

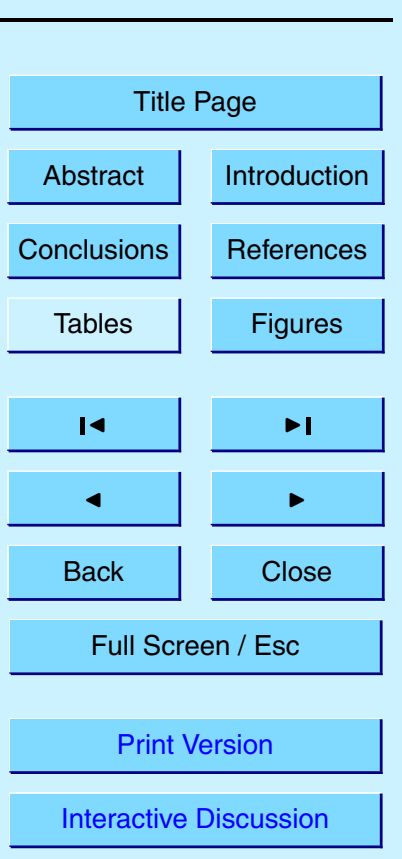

$\mathrm{CN}+\mathrm{O}_{2} \longrightarrow \mathrm{NCO}+\mathrm{O}\left({ }^{3} \mathrm{P}\right)$

$$
\Delta \mathrm{H}_{\mathrm{R}}=-173.4 \mathrm{~kJ} \mathrm{Mole}^{-1}
$$

(C) EGU 2004 
branching ratio $=0.94$

ACPD

$\longrightarrow \mathrm{CO}+\mathrm{NO}$

$\Delta \mathrm{H}_{\mathrm{R}}=-455.6 \mathrm{~kJ} \mathrm{Mole}^{-1}$

4, 5381-5405, 2004

branching ratio $=0.06$.

5 The branching ratio quoted was determined by Schmatjko and Wolfrum (1978). In the laboratory Basco (1965) found that there was a production of ozone due to the first channel of this reaction in an excess of oxygen because it can be followed by

$\mathrm{O}\left({ }^{3} \mathrm{P}\right)+\mathrm{O}_{2} \stackrel{\mathrm{M}}{\longrightarrow} \mathrm{O}_{3}$.

Such a production of $\mathrm{O}_{3}$ does occur in the model to a very small extent, but it is only

a small source of $\mathrm{O}_{3}$ as the $\mathrm{CN}$ radicals are present in such small concentrations. In addition, the $\mathrm{NO}$ formed can then take part in catalytic destruction of $\mathrm{O}_{3}$.

Since $\mathrm{CN}$ is a pseudohalogen it might be expected that, like the halogens, it could take part in the catalytic destruction of ozone, for example

$\mathrm{CN}+\mathrm{O}_{3} \longrightarrow \mathrm{NCO}+\mathrm{O}_{2}$

15

$$
\Delta \mathrm{H}_{\mathrm{R}}=-565.4 \mathrm{~kJ} \mathrm{Mole}^{-1}
$$

$$
\begin{gathered}
\mathrm{NCO}+\mathrm{O}\left({ }^{3} \mathrm{P}\right) \longrightarrow \mathrm{CN}+\mathrm{O}_{2} \\
\Delta \mathrm{H}_{\mathrm{R}}=173.4 \mathrm{~kJ} \mathrm{Mole}^{-1}
\end{gathered}
$$

20 Net: $\mathrm{O}_{3}+\mathrm{O}\left({ }^{3} \mathrm{P}\right) \longrightarrow \mathrm{O}_{2}+\mathrm{O}_{2}$

Clearly the important difference between the pseudo-halogen $\mathrm{CN}$ and halogens such as $\mathrm{Cl}$ and $\mathrm{Br}$, involved in stratospheric ozone destruction, is the very marked difference in their reactions with $\mathrm{O}_{2}$. Chlorine and bromine form weakly bound peroxides on reaction with $\mathrm{O}_{2}$

\section{Atmospheric pseudohalogen chemistry}

D. J. Lary

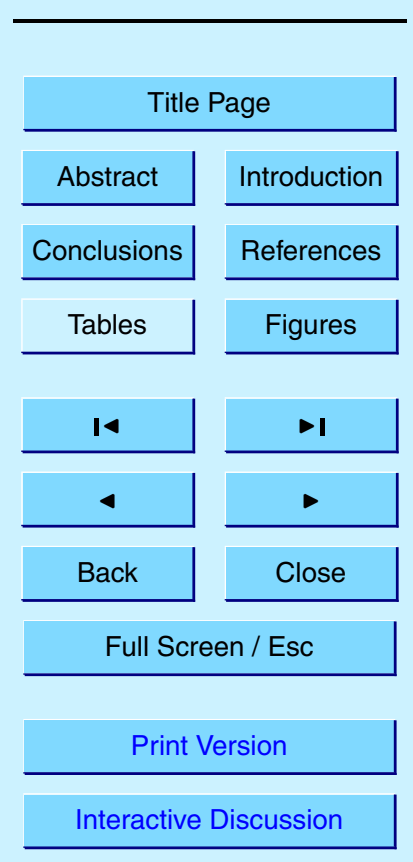

(C) EGU 2004 
which rapidly decompose to give back the halogen, whereas $\mathrm{CN}$ reacts rapidly with $\mathrm{O} 2$, as we have mentioned previously

$$
\mathrm{CN}+\mathrm{O}_{2} \longrightarrow \mathrm{NCO}+\mathrm{O}
$$

${ }_{5} \mathrm{CN}+\mathrm{O}_{2} \rightarrow \mathrm{CO}+\mathrm{NO}$.

Yielding primarily $\mathrm{NCO}$ and $\mathrm{O}$. If $\mathrm{Cl}$ or $\mathrm{Br}$ atoms reacted with $\mathrm{O}_{2}$ in a similar way to $\mathrm{CN}$, there would be no ozone loss. So the $\mathrm{CN}$ radical behaves in a crucially, very different manner to the halogens, preventing it from participating in an efficient ozone loss cycle.

The reaction $\mathrm{CN}+\mathrm{O}_{3}$ is thermodynamically very favorable but its rate constant has not been determined. The $\mathrm{NCO}+\mathrm{O}$ reaction to give $\mathrm{CN}$ as a product occurs in flames (Tsang, 1992). This reaction is endothermic at room temperature by $173 \mathrm{KJ} / \mathrm{Mole}$. So this reaction has not been included in the reaction scheme. Consequently, with the current chemical scheme the only way to convert the NCO formed by the reaction of $\mathrm{CN}$ with $\mathrm{O}_{3}$ back to $\mathrm{CN}$ is via $\mathrm{HCN}$ photolysis. Since $\mathrm{HCN}$ has a lifetime of about 5 months (Singh et al., 2003; Li et al., 2003) and HCN photolysis is extremely slow this is not an effective loss of $\mathrm{O}_{3}$.

The $\mathrm{CN}+\mathrm{O}_{2}$ reaction has a second channel which produces $\mathrm{CO}+\mathrm{NO}$ and so can either enhance the $\mathrm{NO} / \mathrm{NO}_{2}$ catalytic cycle, or enhance the production of odd oxygen if it is followed by the formation and photolysis of $\mathrm{NO}_{2}$. Unlike the photolysis of $\mathrm{NO}_{2}$ or $20 \mathrm{ClO}$, the photolysis of $\mathrm{NCO}$, does not yield an oxygen atom

$\mathrm{NCO}+\mathrm{hv} \longrightarrow \mathrm{N}+\mathrm{CO}$

and so is not a source of odd oxygen. However, it is a source of $\mathrm{N}$ atoms.

3.3. The NCO radical

$\mathrm{NCO}$ is in photochemical equilibrium throughout the sunlit atmosphere. The lifetime varies from about $6 \mathrm{~s}$ at the surface down to about a second at $65 \mathrm{~km}$. The calculated

Atmospheric pseudohalogen chemistry

D. J. Lary

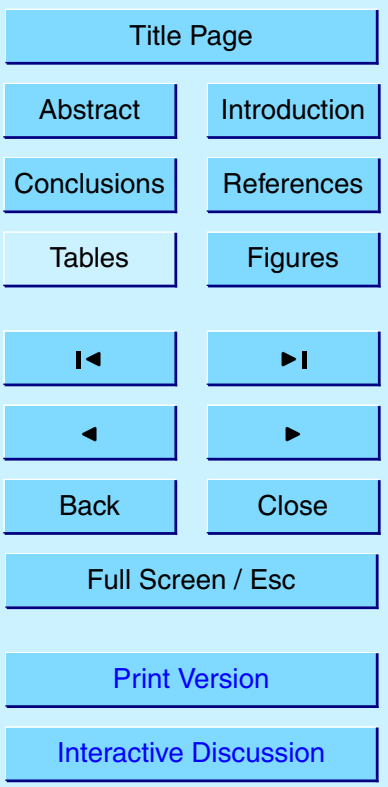

(C) EGU 2004 
NCO profile can be seen in Fig. 4. By far the most important production of NCO is due to the fast reaction

$\mathrm{CN}+\mathrm{O}_{2} \longrightarrow \mathrm{NCO}+\mathrm{O}\left({ }^{3} \mathrm{P}\right)$.

ACPD

The main loss of NCO in the model is

$5 \mathrm{NCO}+\mathrm{O}_{2} \longrightarrow \mathrm{NO}+\mathrm{CO}_{2}$.

In the upper atmosphere the reaction with $\mathrm{O}\left({ }^{3} \mathrm{P}\right)$ also plays a role.

$\mathrm{NCO}+\mathrm{O}\left({ }^{3} \mathrm{P}\right) \longrightarrow \mathrm{CO}+\mathrm{NO}$

\section{Conclusions}

In addition to $\mathrm{NO}_{\mathrm{x}}$ lightning it is suggested that it is also producing significant amounts 10 of $\mathrm{HCN}$ and possibly $\mathrm{HO}_{\mathrm{x}}$. $\mathrm{HCN}$ is a stable, long-lived, sparingly soluble molecule with a long residence time against rain-out. Unlike $\mathrm{NO}_{\mathrm{x}}, \mathrm{HCN}$ can act as a relatively inert "marker" of lightning activity, and may thereby serve as a proxy for the total amount of lightning activity in the atmosphere. The vertical structure of $\mathrm{HCN}$ observed during thunderstorms may provide a good test for the hypothesis that HCN is produced by

15 lightning.

NCO photolysis enhances the $\mathrm{N}$ atom concentration, and hence, enhances the rate of $\mathrm{NO}_{\mathrm{y}}$ loss due to the reaction of $\mathrm{N}$ with $\mathrm{NO}$. This additional source of $\mathrm{N}$ atoms is more important than NO photolysis below $10 \mathrm{~km}$. The NCO absorption cross-section does not appear to have been measured and is one of the largest uncertainties in this study.

20 Acknowledgements. D. Lary thanks J. A. Pyle, Z. Levin, R. Toumi, C. Price and D. Shallcross for useful conversations. It is a pleasure to acknowledge: NASA for a distinguished Goddard Fellowship in Earth Science; The Royal Society for a Royal Society University Research Fellowship; The government of Israel for an Alon Fellowship; The NERC, EU, and ESA for research support.

\section{Atmospheric pseudohalogen chemistry}

D. J. Lary

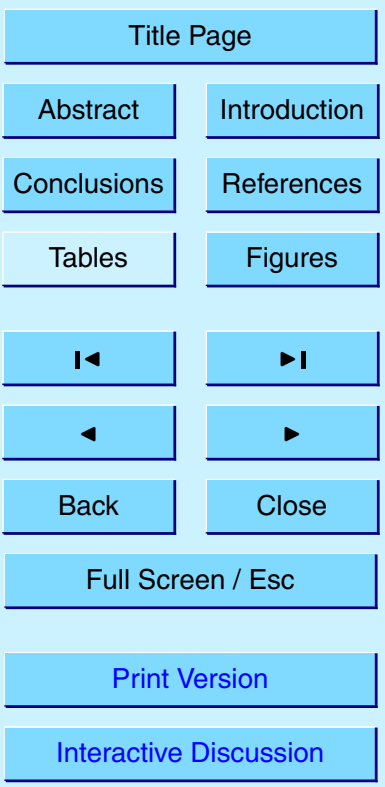

(C) EGU 2004 


\section{References}

Abbas, M., Guo, J., Carli, B., Mencaraglia, F., Carlotti, M., and Nolt, I.: Stratospheric distribution of HCN from far infrared observations, Geophys. Res. Lett., 14, 531-534, 1987. 5383

Anderson, D.: The troposphere-stratosphere radiation-field at twilight - A spherical model, Planet. Space Sci., 31, 1517-1523, 1983. 5389

ATMOS: Data can be accessed from http://remus.jpl.nasa.gov. 5386

Barber, T. R., Lutes, C. C., Doorn, M. R. J., Fuchsman, P. C., Timmenga, H. J., and Crouch, R. L.: Aquatic ecological risks due to cyanide releases from biomass burning, Chemosphere, 50, 343-348, 2003. 5384

Basco, N.: Reaction of Cyanogen Radicals with Oxygen, Proc. of the Royal Society of London Series a-Mathematical and Physical Sciences, 283, 302, 1965. 5392

Becker, G., Grooss, J., McKenna, D., and Muller, R.: Stratospheric photolysis frequencies: Impact of an improved numerical solution of the radiative transfer equation, J. Atmos. Chem., 37, 217-229, 2000. 5389

15 Boldi, R.: A model of the ion chemistry of electrified convection, Tech. Rep. 23, Center for global change Science, MIT, Department of Earth, Atmospheric and Planetary Sciences, 1992. 5386

Borucki, W., Giver, L., Mckay, C., Scattergood, T., and Parris, J.: Lightning production of hydrocarbons and HCN on titan - laboratory measurements, ICARUS, 76, 125-134, 1988. 5385, 5388

Borucki, W., Dyer, J., Phillips, J., and Pham, P.: Pioneer venus orbiter search for venusian lightning, J. Geophys. Res., 96, 11 033-11 043, 1991. 5385, 5388

Bradshaw, J., Sandholm, S., and Talbot, R.: An update on reactive odd-nitrogen measurements made during recent NASA Global Tropospheric Experiment programs, J. Geophys. Res., 103, 19129-19 148, 1998. 5383

Brasseur, G. and Solomon, S.: Aeronomy of the Middle Atmosphere: Chemistry and Physics of the Stratosphere and Mesosphere, Atmospheric Science Library, D. Reidel Pub. Co., 2nd edn., 1987. 5386

Brasseur, G., Zellner, R., Derudder, A., and Arijs, E.: Is hydrogen-cyanide (HCN) a progenitor of acetonitrile $\left(\mathrm{CH}_{3} \mathrm{CN}\right)$ in the atmosphere, Geophys. Res. Lett., 12, 117-120, 1985. 5387, 5390,5391

Britannica, E.: Encyclopaedia Britannica Ultimate Reference Suite 2004 DVD, Encyclopaedia
ACPD

4, 5381-5405, 2004

Atmospheric

pseudohalogen

chemistry

D. J. Lary

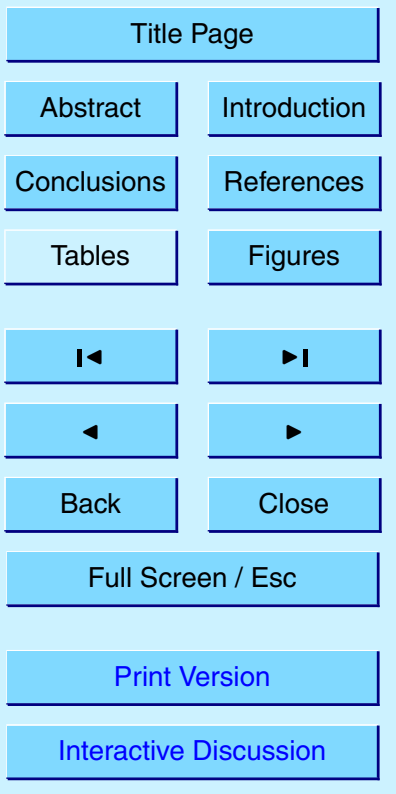

(C) EGU 2004 
Britannica, Inc., 2003. 5383, 5385, 5388

Carli, B. and Park, J.: Simultaneous measurement of minor stratospheric constituents with emission far-infrared spectroscopy, J. Geophys. Res., 29, 3851-3865, 1988. 5383

Cicerone, R. and Zellner, R.: The atmospheric chemistry of hydrogen-cyanide (HCN), J. Geophys. Res., 88, 689-696, 1983. 5383, 5385, 5387, 5388, 5389, 5390, 5391

Coffey, M., Mankin, W., and Cicerone, R.: Spectroscopic detection of stratospheric hydrogen cyanide, Science, 214, 333-335, 1981. 5383

DeMore, W. B., Howard, C. J., Sander, S. P., Ravishankara, A. R., Golden, D. M., Kolb, C. E., Hampson, R. F., Molina, M. J., and Kurylo, M. J.: Chemical Kinetics and Photochemical Data for Use in Stratospheric Modeling, Supplement to Evaluation 12: Update of Key Reactions, JPL Publ. 00-3, 2000. 5389

Farman, J. C., Gardiner, B. G., and Shanklin, J. D.: Large Losses of Total Ozone in Antarctica Reveal Seasonal $\mathrm{ClO}_{x} / \mathrm{NO}_{x}$ Interaction, Nature, 315, 207-210, 1985. 5382

Fisher, M. and Lary, D.: Lagrangian 4-dimensional variational data assimilation of chemical15

species, Q. J. R. Meteorol. Soc., 121, 1681-1704, 1995. 5389

Hauf, T., Schulte, P., Alheit, R., and Schlager, H.: Rapid vertical trace gas-transport by an isolated midlatitude thunderstorm, J. Geophys. Res., 100, 22 957-22 970, 1995. 5388

Herzberg, G. and Innes, K. K.: Ultraviolet Absorption Spectra of HCN and DCN, 1. The Alpha-X and Beta-X Systems, Canadian Journal of Physics, 35, 842-879, 1957. 5390, 5391

20 Hill, R. D.: An Efficient Lightning Energy-Source on the Early Earth, Origins of Life and Evolution of the Biosphere, 22, 277-285, 1992. 5386

Holzinger, R., Warneke, C., Hansel, A., Jordan, A., Lindinger, W., Scharffe, D. H., Schade, G., and Crutzen, P. J.: Biomass burning as a source of formaldehyde, acetaldehyde, methanol, acetone, acetonitrile, and hydrogen cyanide, Geophys. Res. Lett., 26, 1161-1164, 1999. 5384

Huebner, W. F., Keady, J., and Lyon, S.: Solar Photo Rates for Planetary Atmospheres and Atmospheric Pollutants, Kluwer Academic Publishers, Dordrecht, The Netherlands, 1992. 5390

Huntrieser, H., Schlager, H., Feigl, C., and Holler, H.: Transport and production of NOx in electrified thunderstorms: Survey of previous studies and new observations at midlatitudes, J. Geophys. Res., 103, 28247-28264, 1998. 5388

Hurst, D., Griffith, D., Carras, J., Williams, D., and Fraser, P.: Measurements of trace gases emitted by australian savanna fires during the 1990 dry season, J. Atmos. Chem., 18, 33-
ACPD

$4,5381-5405,2004$

\section{Atmospheric \\ pseudohalogen \\ chemistry}

D. J. Lary

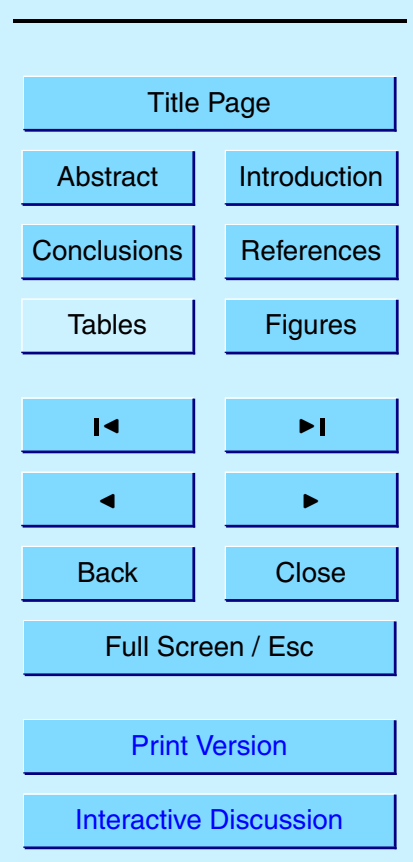

(c) EGU 2004 
56, 1994a. 5384

Hurst, D. F., Griffith, D. W. T., and Cook, G. D.: Trace Gas Emissions from Biomass Burning in Tropical Australian Savannas, J. Geophys. Res.-Atmos., 99, 16 441-16 456, 1994b. 5384

Jaegle, L., Jacob, D., Wennberg, P., Spivakovsky, C., Hanisco, T., Lanzendorf, E., Hintsa, E.,

5 Fahey, D., Keim, E., Proffitt, M., Atlas, E., Flocke, F., Schauffler, S., McElroy, C., Midwinter, C., Pfister, L., and Wilson, J.: Ozone production in the upper troposphere and the influence of aircraft during SONEX: Approach of $\mathrm{NO}_{\mathrm{x}}$-saturated conditions, Geophys. Res. Lett., 26, 3081-3084, 1999. 5386

Jaramillo, M., Dezafra, R. L., Barrett, J. W., Parrish, A., and Solomon, P. M.: Mm-Wave Observations of Stratospheric HCN at Tropical Latitudes, Geophys. Res. Lett., 15, 265-268, 1988. 5383

Jaramillo, M., Dezafra, R. L., Barrett, J., Emmons, L. K., Solomon, P. M., and Parrish, A.: Measurements of Stratospheric Hydrogen-Cyanide at McMurdo Station, Antarctica - Further Evidence of Winter Stratospheric Subsidence, J. Geophys. Res.-Atmos., 94, 16 773-16777, 1989. 5383

Kawakami, S., Kondo, Y., Koike, M., Nakajima, H., Gregory, G., Sachse, G., Newell, R., Browell, E., Blake, D., Rodriguez, J., and Merrill, J.: Impact of lightning and convection on reactive nitrogen in the tropical free troposphere, J. Geophys. Res., 102, $28367-28384,1997.5388$

Kliner, D., Daube, B., Burley, J., and Wofsy, S.: Laboratory investigation of the catalytic reduction technique for measurement of atmospheric $\mathrm{NO}_{y}$, J. Geophys. Res., 102, 10 759-10 776, 1997. 5383

Kopp, E.: Hydrogen Constituents of the Mesosphere Inferred from Positive-Ions - H2o, Ch4, H2co, H2o2, and Hcn, J. Geophys. Res.-Atmos., 95, 5613-5630, 1990. 5383

Kuhlbusch, T., Lobert, J., Crutzen, P., and Warneck, P.: Molecular nitrogen emissions from 25

denitrification during biomass burning, Nature, 351, 135-137, 1991. 5384

Lary, D.: Gas phase atmospheric bromine photochemistry, J. Geophys. Res., 101, 1505-1516, 1996. 5389

Lary, D. and Pyle, J.: Diffuse-radiation, twilight, and photochemistry: 1., J. Atmos. Chem., 13, 373-392, 1991a. 5389

30 Lary, D. and Pyle, J.: Diffuse-radiation, twilight, and photochemistry: 2., J. Atmos. Chem., 13, 393-406, 1991b. 5389

Lary, D., Chipperfield, M., and Toumi, R.: The potential impact of the reaction $\mathrm{OH}+\mathrm{ClO} \longrightarrow \mathrm{HCl}+\mathrm{O}_{2}$ on polar ozone photochemistry, J. Atmos. Chem., 21, 61-79, 1995.
ACPD

4, 5381-5405, 2004

Atmospheric

pseudohalogen

chemistry

D. J. Lary

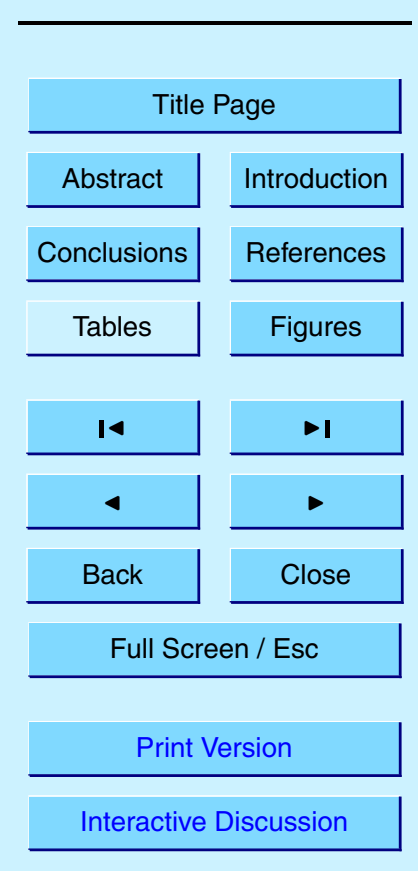

(c) EGU 2004 
Lary, D. J., Khattatov, B., and Mussa, H. Y.: Chemical data assimilation: A case study of solar occultation data from the ATLAS 1 mission of the Atmospheric Trace Molecule Spectroscopy Experiment (ATMOS), J. Geophys. Res.-Atmos., 108, 2003. 5389

5 Lee, D. and Atkins, D.: Atmospheric ammonia emissions from agricultural waste combustion, Geophys. Res. Lett., 21, 281-284, 1994. 5384

Li, Q. B., Jacob, D. J., Yantosca, R. M., Heald, C. L., Singh, H. B., Koike, M., Zhao, Y. J., Sachse, G. W., and Streets, D. G.: A global three-dimensional model analysis of the atmospheric budgets of $\mathrm{HCN}$ and $\mathrm{CH} 3 \mathrm{CN}$ : Constraints from aircraft and ground measurements, J. Geophys. Res.-Atmos., 108, $\mathbf{W}$, 2003. 5384, 5387, 5390, 5393

Lobert, J. M., Scharffe, D. H., Hao, W. M., and Crutzen, P. J.: Importance of Biomass Burning in the Atmospheric Budgets of Nitrogen-Containing Gases, Nature, 346, 552-554, 1990. 5384

Mahieu, E., Rinsland, C. P., Zander, R., Demoulin, P., Delbouille, L., and Roland, G.: Vertical Column Abundances of Hcn Deduced from Ground-Based Infrared Solar Spectra - Long-

15 Term Trend and Variability, J. Atmos. Chem., 20, 299-310, 1995. 5383

Mahieu, E., Zander, R., Delbouille, L., Demoulin, P., Roland, G., and Servais, C.: Observed trends in total vertical column abundances of atmospheric gases from IR solar spectra recorded at the Jungfraujoch, J. Atmos. Chem., 28, 227-243, 1997. 5383

Meier, R., Anderson, D., and Nicolet, M.: Radiation-field in the troposphere and stratosphere from 240-1000 nm, 1., General-Analysis, Planet. Space Sci., 30, 923-933, 1982. 5389

NCEP: Data can be accessed from http://www.ncep.noaa.gov. 5387

Nicolet, M., Meier, R., and Anderson, D.: Radiation-field in the troposphere and stratosphere, 2. Numerical-Analysis, Planet. Space Sci., 30, 935-983, 1982. 5389

Notholt, J., Meier, A., and Peil, S.: Total column densities of tropospheric and stratospheric 25 trace gases in the undisturbed arctic summer atmosphere, J. Atmos. Chem., 20, 311-332, 1995. 5383

Pickering, K., Wang, Y., Tao, W., Price, C., and Muller, J.: Vertical distributions of lightning $\mathrm{NO}_{\mathrm{x}}$ for use in regional and global chemical transport models, J. Geophys. Res., 103, 3120331216, 1998. 5387

30 Press, W., Teukolsky, S., Vetterling, W., and Flannery, B.: Numerical Recipes in Fortran - The Art of Scientific Computing, Cambridge Univ. Press, New York, 2nd edn., 1992. 5389

Price, C. and Rind, D.: Possible implications of global climate-change on global lightning distributions and frequencies, J. Geophys. Res.-Atmos., 99, 10823-10 831, 1994. 5386

\section{Atmospheric \\ pseudohalogen \\ chemistry}

D. J. Lary

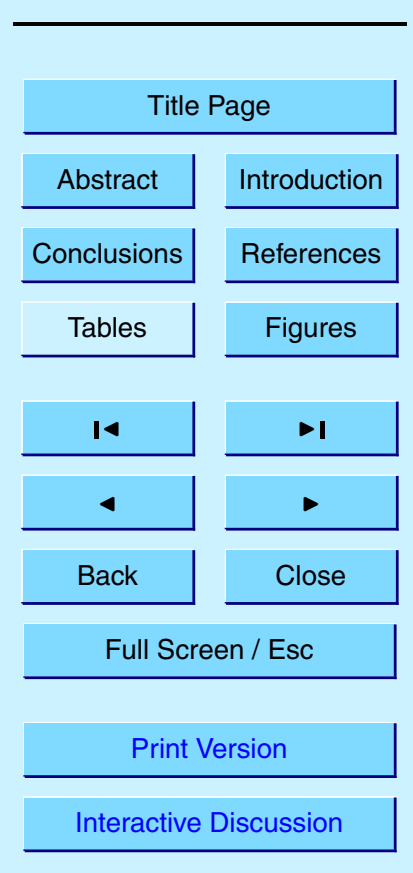

(C) EGU 2004 
Rinsland, C., Mahieu, E., Zander, R., Gunson, M., Salawitch, R., Chang, A., Goldman, A., Abrams, M., Abbas, M., Newchurch, M., and Irion, F.: Trends of OCS, HCN, $\mathrm{SF}_{6}, \mathrm{CHClF}_{2}$ in the lower stratosphere from 1985 and 1994 ATMOS experiment measurements near $30^{\circ} \mathrm{N}$ latitude, Geophys. Res. Lett., 23, 2349-2352, 1996. 5383

5 Rinsland, C., Gunson, M., Wang, P., Arduini, R., Baum, B., Minnis, P., Goldman, A., Abrams, M., Zander, R., Mahieu, E., Salawitch, R., Michelsen, H., Irion, F., and Newchurch, M.: ATMOS/ATLAS-3 infrared profile measurements of trace gases in the November 1994 tropical and subtropical upper troposphere, J. Quant. Spec. Rad. Trans., 60, 891-901, 1998a. 5383

10 Rinsland, C., Gunson, M., Wang, P., Arduini, R., Baum, B., Minnis, P., Goldman, A., Abrams, M., Zander, R., Mahieu, E., Salawitch, R., Michelsen, H., Irion, F., and Newchurch, M.: ATMOS/ATLAS-3 infrared profile measurements of clouds in the tropical and subtropical upper troposphere, J. Quant. Spec. Rad. Trans., 60, 903-919, 1998b. 5383

Rinsland, C. P., Goldman, A., Murcray, F. J., Stephen, T. M., Pougatchev, N. S., Fishman, J., 15 David, S. J., Blatherwick, R. D., Novelli, P. C., Jones, N. B., and Connor, B. J.: Infrared solar spectroscopic measurements of free tropospheric $\mathrm{CO}, \mathrm{C}_{2} \mathrm{H}_{6}$, and $\mathrm{HCN}$ above Mauna Loa, Hawaii: Seasonal variations and evidence for enhanced emissions from the Southeast Asian tropical fires of 1997-1998, J. Geophys. Res.-Atmos., 104, 18667-18680, 1999. 5383, 5384

Rinsland, C. P., Mahieu, E., Zander, R., Demoulin, P., Forrer, J., and Buchmann, B.: Free tropospheric $\mathrm{CO}, \mathrm{C}_{2} \mathrm{H}_{6}$, and $\mathrm{HCN}$ above central Europe: Recent measurements from the Jungfraujoch station including the detection of elevated columns during 1998, J. Geophys. Res.-Atmos., 105, 24 235-24249, 2000. 5383, 5384

Rinsland, C. P., Meier, A., Griffith, D. W. T., and Chiou, L. S.: Ground-based measurements of tropospheric $\mathrm{CO}, \mathrm{C}_{2} \mathrm{H}_{6}$, and $\mathrm{HCN}$ from Australia at 34 degrees $\mathrm{S}$ latitude during 1997-1998, J. Geophys. Res.-Atmos., 106, 20 913-20 924, 2001. 5383

Schade, G. and Crutzen, P.: Emission of aliphatic-amines from animal husbandry and their reactions - potential source of $\mathrm{N}_{2} \mathrm{O}$ and $\mathrm{HCN}$, J. Atmos. Chem., 22, 319-346, 1995. 5384

Schmatjko, K. J. and Wolfrum, J.: Reactions of Molecules in Defined Vibrational-States, 6. Energy-Distribution in Reactions $\mathrm{CN}(\mathrm{V})+\mathrm{O}\left({ }^{3} \mathrm{P}\right), \mathrm{O}_{2}$, Berichte Der Bunsen-GesellschaftPhysical Chemistry, Chemical Physics, 82, 419-428, 1978. 5392

Schneider, J., Burger, V., and Arnold, F.: Methyl cyanide and hydrogen cyanide measurements in the lower stratosphere: Implications for methyl cyanide sources and sinks, J. Geophys. Res., 102, 25501-25506, 1997. 5383
ACPD

4, 5381-5405, 2004

Atmospheric

pseudohalogen

chemistry

D. J. Lary

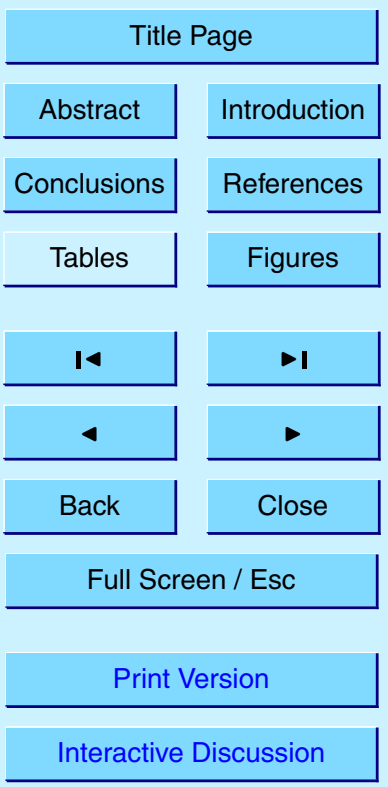

(C) EGU 2004 
Singh, H. B., Salas, L., Herlth, D., Kolyer, R., Czech, E., Viezee, W., Li, Q., Jacob, D. J., Blake, D., Sachse, G., Harward, C. N., Fuelberg, H., Kiley, C. M., Zhao, Y., and Kondo, Y.: In situ measurements of $\mathrm{HCN}$ and $\mathrm{CH} 3 \mathrm{CN}$ over the Pacific Ocean: Sources, sinks, and budgets, J. Geophys. Res.-Atmos., 108, 2003. 5383, 5384, 5387, 5390, 5393

5 Smith, M. A. H. and Rinsland, C. P.: Spectroscopic Measurements of Atmospheric HCN at Northern and Southern Latitudes, Geophys. Res. Lett., 12, 5-8, 1985. 5383

Stoer, J. and Bulirsch, R.: Introduction to Numerical Analysis, Springer-Verlag, New York, 1980. 5389

Takahashi, S.: The reaction between methane and nitrogen atom, Mem. Def. Acad., Math.,

10 Phys., Chem. Eng. (Yokosuka, Jpn.), 12, 1972. 5390

Thompson, A., Singh, H., Stewart, R., Kucsera, T., and Kondo, Y.: A Monte Carlo study of upper tropospheric reactive nitrogen during the Pacific Exploratory Mission in the Western Pacific Ocean (PEM-West B), J. Geophys. Res., 102, 28 437-28 446, 1997. 5383

Toon, G., Farmer, C., Schaper, P., Lowes, L., and Norton, R.: Composition measurements of 15 the 1989 arctic winter stratosphere by airborne infrared solar absorption-spectroscopy, J. Geophys. Res., 97, 7939-7961, 1992a. 5383

Toon, G., Farmer, C., Schaper, P., Lowes, L., Norton, R., Schoeberl, M., Lait, L., and Newman, P.: Evidence for subsidence in the 1989 arctic winter stratosphere from airborne infrared composition measurements, J. Geophys. Res., 97, 7963-7970, 1992b. 5383

20 Tsang, W.: Chemical Kinetic Data-Base for Propellant Combustion - Reactions Involving Cn, Nco, and Hnco, J. Phys. Chem. Ref. Data, 21, 753-791, 1992. 5393

Yokelson, R., Susott, R., Ward, D., Reardon, J., and Griffith, D.: Emissions from smoldering combustion of biomass measured by open-path Fourier transform infrared spectroscopy, J. Geophys. Res., 102, 18 865-18877, 1997a. 5384

Yokelson, R. J., Susott, R., Ward, D. E., Reardon, J., and Griffith, D. W. T.: Emissions from smoldering combustion of biomass measured by open-path Fourier transform infrared spectroscopy, J. Geophys. Res.-Atmos., 102, 18865-18877, 1997b. 5384

Yokelson, R. J., Bertschi, I. T., Christian, T. J., Hobbs, P. V., Ward, D. E., and Hao, W. M.: Trace gas measurements in nascent, aged, and cloud-processed smoke from African savanna fires 30 by airborne Fourier transform infrared spectroscopy (AFTIR), J. Geophys. Res.-Atmos., 108, —, 2003. 5383, 5384

Zahnle, K. J.: Photochemistry of Methane and the Formation of Hydrocyanic Acid (HCN) in the Earths Early Atmosphere, J. Geophys. Res.-Atmos., 91, 2819-2834, 1986a. 5387, 5390

ACPD

$4,5381-5405,2004$

Atmospheric

pseudohalogen

chemistry

D. J. Lary

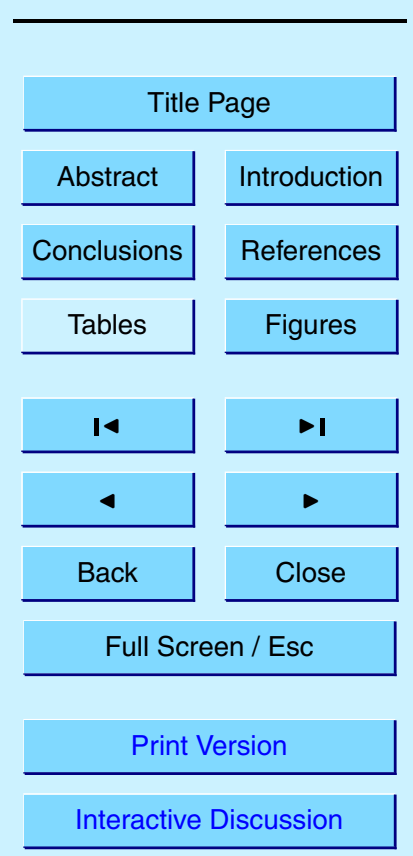

(c) EGU 2004 
Zahnle, K. J.: Photochemistry of $\mathrm{CH}_{4}$ and $\mathrm{HCN}$ in the Primitive Atmosphere, Origins of Life and Evolution of the Biosphere, 16, 188-189, 1986b. 5387, 5390

Zander, R. et al. Concentrations of carbonyl sulfide and hydrogen cyanide in the free upper troposphere and lower stratosphere deduced from ATMOS/Spacelab-3 infrared solar occultation spectra, J. Geophys. Res., 93, 1669-1678, 1988. 5383, 5385

Zhao, Y., Kondo, Y., Murcray, F. J., Liu, X., Koike, M., Irie, H., Strong, K., Suzuki, K., Sera, M., and Ikegami, Y.: Seasonal variations of HCN over northern Japan measured by groundbased infrared solar spectroscopy, Geophys. Res. Lett., 27, 2085-2088, 2000. 5383

Zhao, Y., Strong, K., Kondo, Y., Koike, M., Matsumi, Y., Irie, H., Rinsland, C. P., Jones, N. B., Suzuki, K., Nakajima, H., Nakane, H., and Murata, I.: Spectroscopic measurements of tropospheric $\mathrm{CO}, \mathrm{C}_{2} \mathrm{H}_{6}, \mathrm{C}_{2} \mathrm{H}_{2}$, and $\mathrm{HCN}$ in northern Japan, J. Geophys. Res.-Atmos., 107, 2002. 5383

ACPD

4, 5381-5405, 2004

Atmospheric

pseudohalogen

chemistry

D. J. Lary

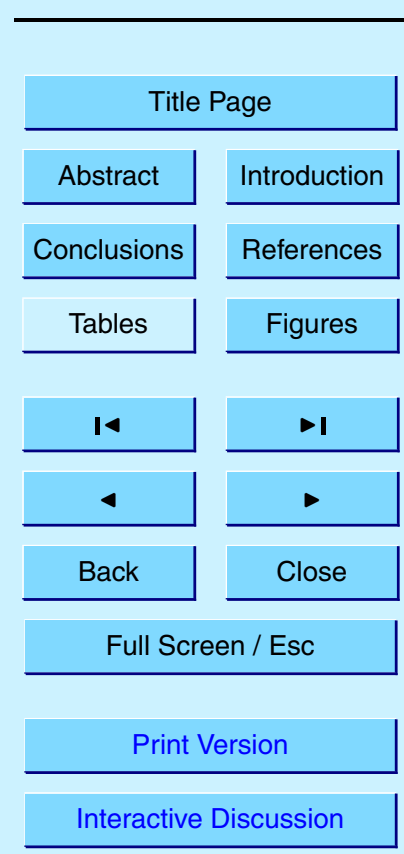

(C) EGU 2004 


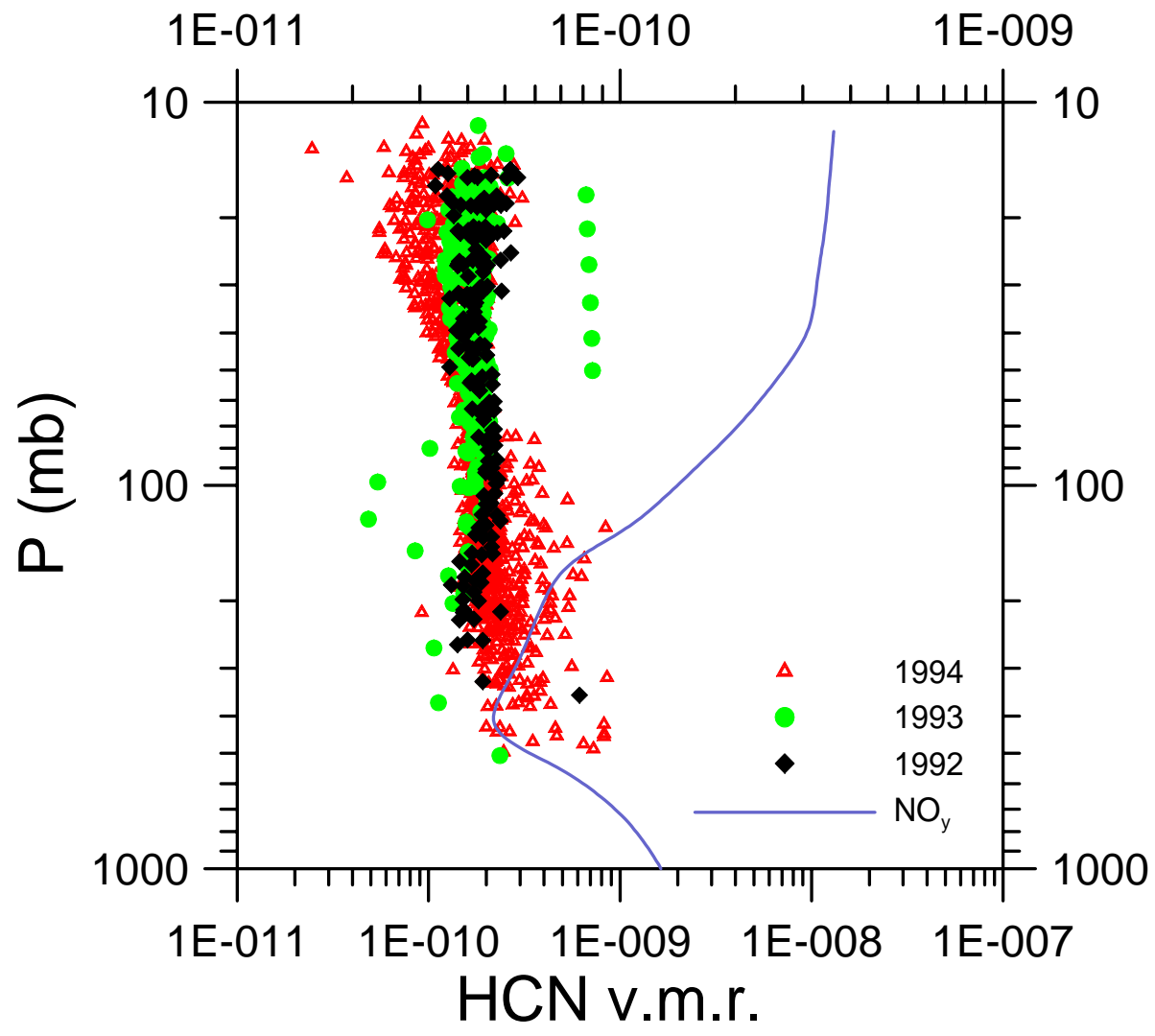

Fig. 1. All HCN observations made by the Atmospheric Trace Molecule Spectroscopy Experiment (ATMOS) on the missions ATLAS-1 (1992), ATLAS-2 (1993), and ATLAS-3 (1994) shown together with a typical mid-latitude $\mathrm{NO}_{y}$ profile. The ATMOS data is publically available from the web site http://remus.jpl.nasa.gov/.

\section{ACPD}

4, 5381-5405, 2004

Atmospheric pseudohalogen chemistry

D. J. Lary

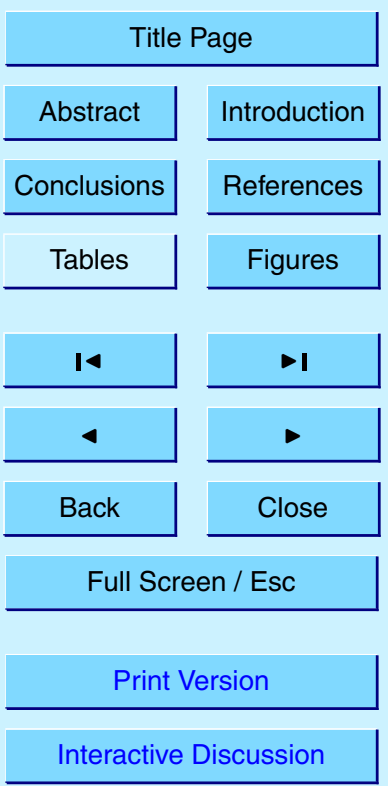

(C) EGU 2004 


\section{ACPD}

$4,5381-5405,2004$
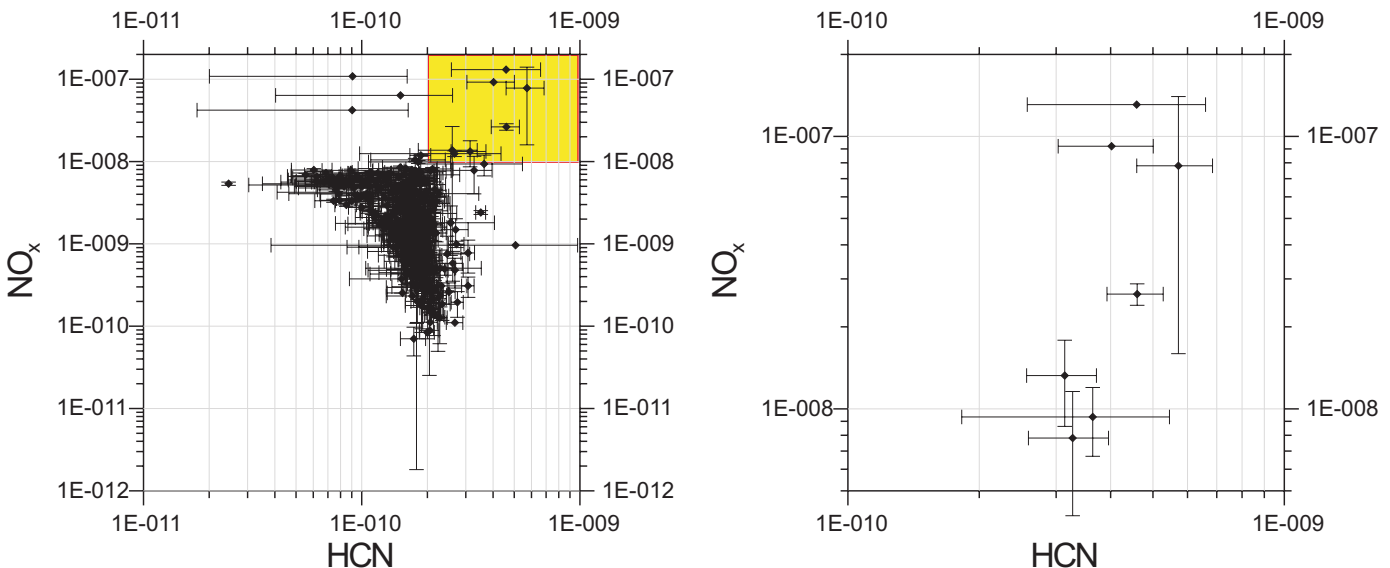

\section{Atmospheric pseudohalogen chemistry}

D. J. Lary

Fig. 2. Scatter diagram of the $\mathrm{HCN}$ and $\mathrm{NO}_{\mathrm{x}}$ concentrations observed by ATMOS ATLAS3. The left hand panel shows all the available $\mathrm{HCN}$ and $\mathrm{NO}_{x}$ observations made. The right hand panel is an enlargement showing just the high $\mathrm{NO}_{x}$ and $\mathrm{HCN}$ concentrations which are probably associated with lightning (notice the log-log scale).

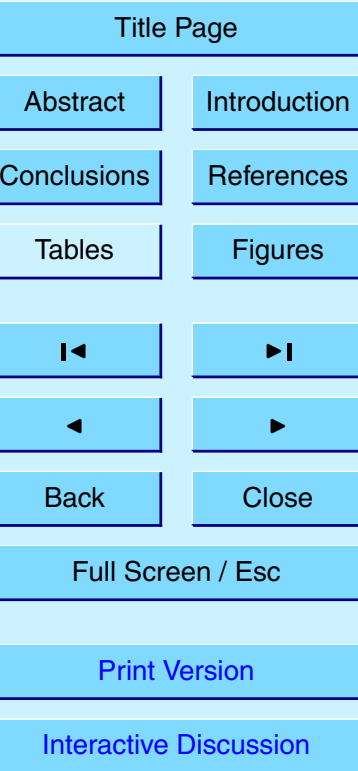

(C) EGU 2004 


\section{ACPD}

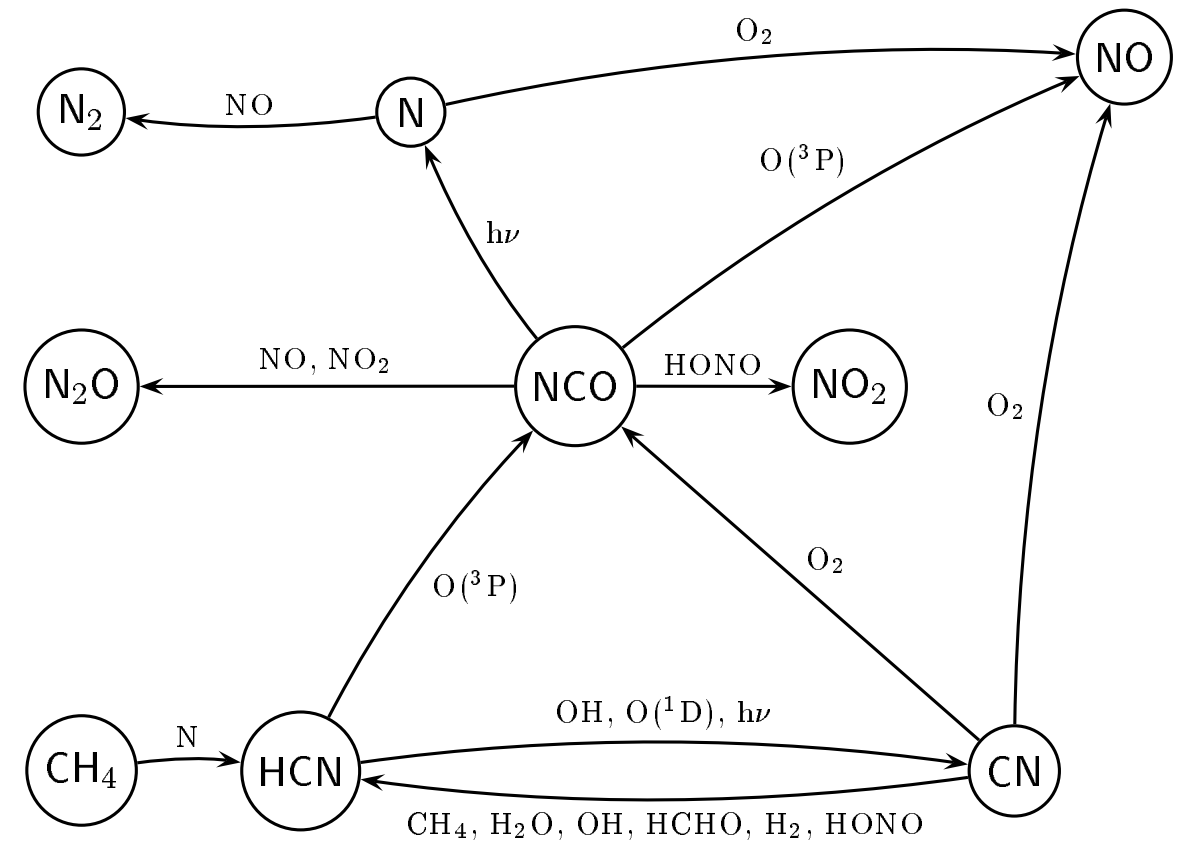

$4,5381-5405,2004$

Atmospheric pseudohalogen chemistry

D. J. Lary

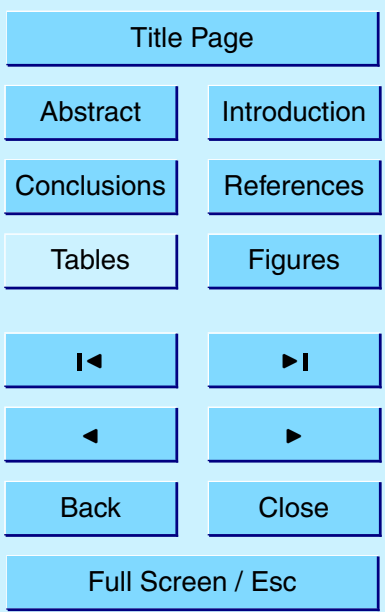

Fig. 3. The $\mathrm{CN}, \mathrm{NCO}, \mathrm{HCN}$ reaction scheme used in the model.

Print Version

Interactive Discussion

(C) EGU 2004 

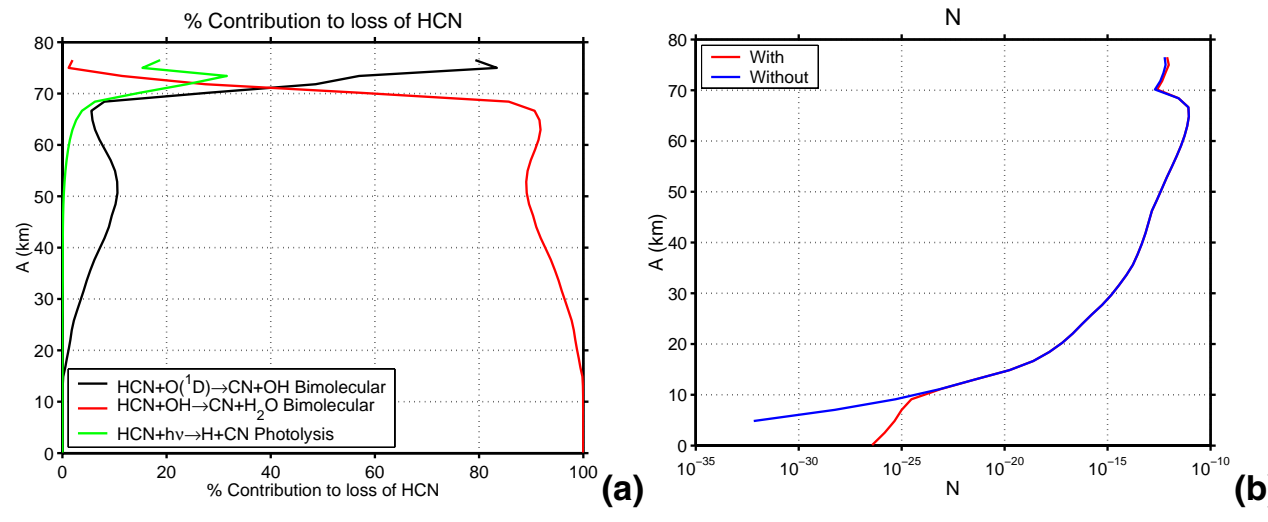

$\log _{10}(\mathrm{CN})$

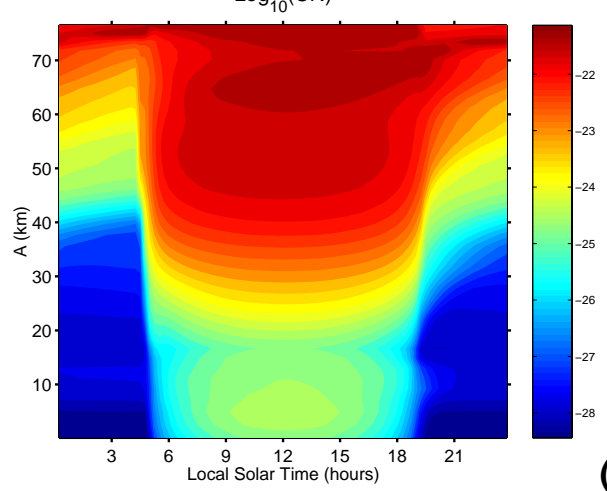

(c)

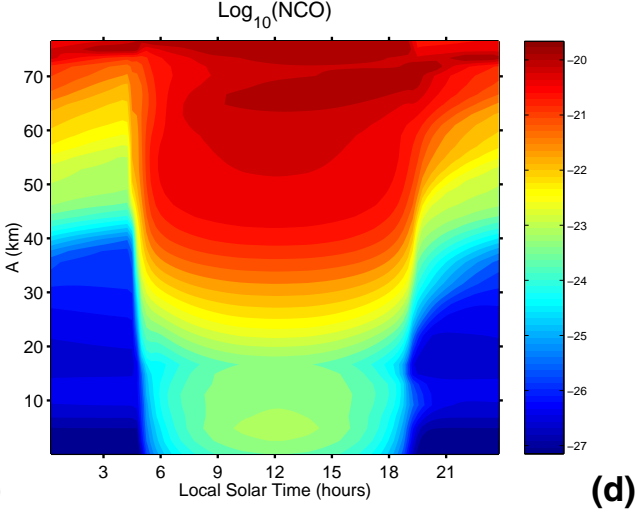

Fig. 4. Panel (a) shows the calculated contributions for the various loss terms of HCN. Panel (b) shows the effect on the nitrogen atom v.m.r. when cyanide chemistry is included. The red line shows the calculation with pseudohalogen chemistry the blue line shows the calculation without pseudohalogen chemistry. Panels (c) and (d) show calculated diurnal cycles for CN and NCO.
ACPD

$4,5381-5405,2004$

Atmospheric

pseudohalogen

chemistry

D. J. Lary

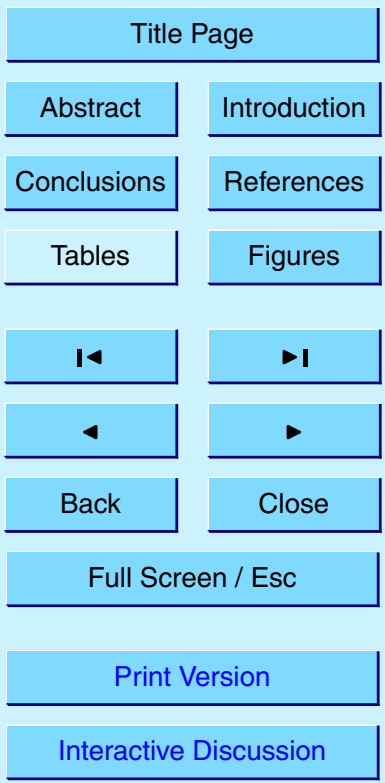

(C) EGU 2004 